Indexed by:

Asinta

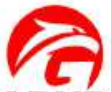

GARUDA

Crossref

Crossmark

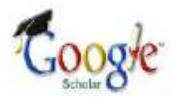

Dimensions

ones

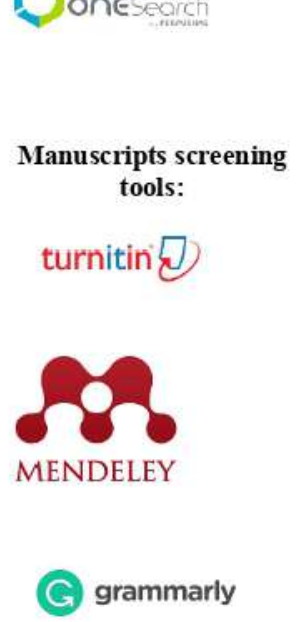

Key words:

Resort hotels, Tropical Climate, Natural Lighting

\section{Triana Paramita}

Mahasiswa Jurusan Arsitektur

FTSP, Universitas Trisakti,

Jakarta, Indonesia

Jl. Kyai Tapa No. 1 RT.6/RW.16, Grogol

Kec. Grogol Petamburan, Kota Jakarta

Barat, Daerah Khusus Ibukota Jakarta

11440

\author{
Agus Saladin \\ Dosen Jurusan Arsitektur FTSP, \\ Universitas Trisakti, Jakarta, \\ Indonesia \\ J1. Kyai Tapa No. 1 RT.6/RW.16, Grogol \\ Kec. Grogol Petamburan, Kota Jakarta \\ Barat, Daerah Khusus Ibukota Jakarta \\ 11440
}

\author{
Nuzuliar Rahma \\ Dosen Jurusan Arsitektur FTSP, \\ Universitas Trisakti, Jakarta, \\ Indonesia \\ J1. Kyai Tapa No. 1 RT.6/RW.16, Grogol \\ Kec. Grogol Petamburan, Kota Jakarta \\ Barat, Daerah Khusus Ibukota Jakarta \\ 11440
}

Doi:

10.17509/jaz.v4i1.27141

Cite article:

Paramita, T., Saladin, A., dan Rahma, N. (2021). Pemanfaatan Pencahayaan Alami Iklim Tropis pada Bangunan Hotel Resort di Bali. Jurnal Arsitektur Zonasi, 4(1), 114-120. https://doi.org/doi.org/10.17509/jaz.v4i1.27141

Akses online:

untuk naskah lengkap tersedia di: https://ejournal.upi.edu/index.php/jaz/issue/archive 
http://ejournal.upi.edu/index.php/jaz - e-mail:_jurnal_zonasi@upi.edu doi.org/10.17509/jaz.v4i1.27141

\section{PEMANFAATAN PENCAHAYAAN ALAMI IKLIM TROPIS PADA BANGUNAN HOTEL RESORT DI BALI}

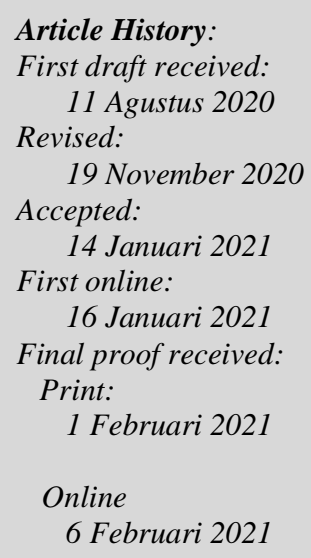

Jurnal Arsitektur ZONASI is indexed and listed in several databases:

\section{SINTA 4 (Arjuna)}

GARUDA (Garda Rujukan Digital) Google Scholar

Dimensions

oneSearch

BASE

Member:
Crossref
RJI
APTARI
FJA (Forum Jurna Arsitektur)
IAI
AJPKM

\section{Pendahuluan}

Pulau Bali merupakan salah satu daerah pariwisata di Indonesia yang sangat terkenal dengan iklim tropis. Selain kekayaan alam dan budaya, iklim merupakan daya tarik utama wisatawan di Bali. Oleh karena itu, bangunan di Bali, terutama hotel resort yang merupakan akomodasi pariwasata, diharapkan memanfaatkan pencahayaan alami pada desainnya secara maksimal. Untuk mendapatkan desain yang merespon cahaya alami seacara maksimal, perlu diterapkan beberapa proses pada perancangannya yaitu dengan cara memperhatikan pengolahan sinar matahari yang masuk ke dalam bangunan. Tujuan dari penulisan jurnal ini adalah mendapatkan proses dan inovasi baru untuk merespon cahaya alami dalam perancangan hotel resort.

Menurut Tri Harso Karyono, terkait dengan intensitas cahaya atau level penerangan (daylight level) dalam satuan lux, kontras (contrast) dan silau (glare). Proses pencahayaan dalam merangcang merupakan

\author{
Triana Paramita ${ }^{1}$ \\ Agus Saladin ${ }^{2}$ \\ Nuzuliar Rahma ${ }^{3}$ \\ 1, Mahasiswi Jurusan Arsitektur, FTSP, Universitas Trisakti \\ 2,3 Dosen Jurusan Arsitektur, FTSP, Universitas Trisakti, Jakarta \\ Jl. Kyai Tapa No.1, RT.6/RW.16, Grogol, Kec. Grogol Petamburan, Kota Jakarta Barat, \\ agus.saladin@trisakti.ac.id \\ 3nuzuliar@trisakti.ac.id
}

\begin{abstract}
Indonesia which is located in the equator causes Indonesia to have tropical climate or can be called hot climate. Tropical climates are rich in sun resources, as well as in Bali Island. Trust is an important aspect that should be noticed in designing a building, the tion of natural lighting can be applied to the resort hotel building in Bali. The utilization of natural light also causes energy saving, with optimal natural lighting utilization through the opening, orientation and window area that can affect a lot of incoming light. The method xsused is a qualitative method by collecting data sources and taking some samples or precedent studies from a realised building.
\end{abstract}

Keywords: Resort hotels, Tropical Climate, Natural Lighting.

Abstrak: Indonesia yang terletak di garis khatulistiwa menyebabkan Indonesia memiliki iklim tropika atau bisa disebut iklim panas. Daerah beriklim tropis kaya akan sumber daya sinar matahari, begitu pula di Pulau Bali. Percahayaan merupakan aspek penting yang harus iperhatikan dalam merancang suatu bangunan, pemanfaatan pencahayaan alami ini dapat adanya penghematan energi, dengan pemanfaatan pencahayaan alami yang optimal melalui bukaan, orientasi dan luas jendela yang dapat mempengaruhi banyak cahaya yang masuk. Metode yang digunakan adalah metode kualitatif dengan mengumpulkan sumber-sumber terealisasikan.

Kata Kunci: Hotel Resort, Iklim Tropis, Pencahayaan Alami. 
faktor yang sangat penting dan harus sangat diperhatikan, orientasi arah dari sinar matahari berpengaruh terhadap peletakan massa bangunan, bentuk dan ukuran bukaan atau jendela menjadi salah satu hal yang harus di pertimbangkan dalam optimalisasi pencahayaan di siang hari. Pencahayaan alami juga harus sesuai dengan standar kenyamanan dari masing-masing penghuni ruang, dan terkadang juga perlunya kenyamanan visual dalam memanfaatkan cahaya alami

Bangunan di wilayah Pulau Bali terutama bangunan hotel resort rata-rata memiliki design fasad bangunan yang bersifat terbuka atau memiliki banyaknya bukaan, bangunan yang di rancang dengan banyaknya bukaan bahkan ada beberapa bangunan utama seperti lobby atau restaurant pada hotel resort yang di desain sangat terbuka bahkan tidak menggunakan dinding.

Selain dengan penghematan energi pada bangunan pemanfaatan pencahayaan alami juga dapat meningkatkan estetika dari permainan pencahayaan dan permainan bayangan. Dengan iklim di daerah pantai yang panas, pemanfaatan angin pantai yang sejuk adalah sebuah opsi atau pilihan yang akan menjadi salah satu daya tarik pengunjung yaitu dari segi kenyamanan thermal pada bangunan hotel resort, adanya kenyamanan thermal pada setiap pengunjung atau manusia pastinya berbeda-beda, hampir sebagian pengunjung hotel resort adalah warga asing. Maka dari itu sangat diperlukannya pencahayaan alami yang tepat, tidak hanya memasukan cahaya tapi juga menyaring atau menyusuaikan dengan kenyamanan thermal.

Pencahayaan alami adalah sebuah cahaya yang berasal dari sumber daya alam atau penerangan alami seperti matahari, bintang, dan bulan sebagai penerangan ruang. Karena berasal dari alam, sebuah cahaya yang masuk ke dalam bangunan atau ruang akan memiliki sifat yang tidak menentu, bergantung pada iklim, musim, cuaca, dan juga dari pemanfaatan warna interior, material, fasad, dan sebagainya yang bisa memantulkan sebuah cahaya. Seperti sebuah dinding di bandingkan dinding atau fasad yang gelap, dinding yang berwarna putih atau terang pasti lebih bisa memantulkan cahaya yang di dapat ke ruang yang intensitas cahaya alaminya kurang. Dan matahari yang merupakan sinar yang paling besar dari semua sumber pencahayaan alami sehingga matahari adalah pengcahyaan yang paling sering dimanfaatkan dan sangat berguna dalam pencahayaan dalam ruangan. Menurut P. Dora dan P. Nilasari (2011), pencahayaan alami dari matahari langsung untuk penerangan interior disebut dengan daylight.

Pencahayaan alami memiliki energi cahaya yang akan dihasilkan oleh sinar matahari dan berpengaruh pada tingkat kenyamanan visual didalam bangunan, sedangkan energi panas yang di hasilkan dari sinar matahari akan berimplikasi pada kenyamanan termal. Menurut Koenigsberger (1975), iklim dimana panas merupakan masalah yang dominan adalah iklim tropis yang "bertugas" mendinginkan pemakai hampir pada keseluruhan waktu dalam satu tahun bangunan, dari pada menghangatkan dan suhu rata-rata pertahun kurang dari $200 \mathrm{C}$.

Menurut Sulastiyono (2011), Hotel adalah sebuah perusahaan yang mana dijalankan dan diatur oleh sang pemiliknya dengan menyediakan fasilitas-fasilitas seperti penyediaan tempat istirahat, makanan, minuman, hingga fasilitas kamar tidur kepada orang-orang yang melakukan perjalanan dan berkecukupan untuk membayar sejumlah uang yang wajar dan tidak adanya perjanjian khusus apapun.

Pengertian hotel dari segi arsitektur yaitu hotel dapat di definisikan sebagai bangunan penginapan yang diatur, control, dan kembangkan secara komersial yang juga harus menyediakan berbagai fasilitas dan pelayanan baik dari fasilitas makanan dan minuman hingga fasilitas menunjang seperti adanya kolam renang atau sport center, bangunan hotel yang memiliki perancangan yang baik akan lebih mendapatkan minat pengunjung yang tinggi. Adapun pengertian resort, menurut Coltmant (1895) yang mengatakan bahwa resort juga banyak dijumpai pada sebuah daerah-daerah tujuan yang juga tidak hanya diperuntukkan bagi orangorang yang singgah untuk sementara waktu. Resort juga didesain untuk para wisatawan yang berekreasi dari berbagai wilayah atau bahkan belahan dunia. Dan juga ada beberapa tipe Resort diantaranya dimulai dari tipe resort sederhana sampai ada dengan resort mewah, yang dapat memenuhi berbagai jenis kebutuhan mulai dari keluarga bahkan maupun kebutuhan bisnis. Resort biasanya berlokasi di tempat-tempat yang memiliki keindahan alam seperti sebuah pantai, hutan, atau pegunungan, atau juga sebuah fasilitas-fasilitas yang disediakan seperti lapangan golf, lapangan tenis, dan sebagainya.

Berdasarkan kedua pengertian tersebut dapat disimpulkan bahwa sebuah hotel resort adalah tempat menginap yang mengutamakan potensi lingkungan alam sekitar tapak pada perancangannya. Hotel resort biasa identik dengan perancangan bangunannya yang memiliki sifat terbuka dan merespon lingkungan, termasuk iklim. Oleh karena itu hotel resort di bali sangat perlu merespon iklim tropis pada perancangannya dengan pengolahan bukaan yang maksimal. 


\section{Metode Penelitian}

Metode penelitian yang digunakan penulis adalah metode kualitatif. Objek penelitian ini adalah perancangan hotel resort di wilayah pulau Bali. Berikut proses kegiatan penelitian :

1. Mengumpulkan data-data yang bersumber dari berbagai buku, kajian, dan artikel

2. Melakukan kunjungan ke hotel resort Potato Head Bali dan The Ayana Bali, serta menambahkan beberapa studi preseden

3. Menganalisa hasil studi preseden yang disesuaikan dengan tinjauan pustaka

4. Mengimplementasikan hasil Analisa ke dalam studi kasus

\section{Hasil dan Pembahasan}

Pemanfaatan pencahayaan alami pada sebuah bangunan hotel resort di daerah pantai kuta bali. wilayah yang cukup hangat dan memiliki iklim tropis. Iklim dan panas menjadi salah satu kelebihan yang dapat di aplikasi kan dalam perancangan ruang - ruang yang ada di dalam maupun area luar bangunan. Hal- hal yang perlu di perhatikan dalam perancangan adalah :

\section{Mengetahui arah dan pantulan sinar matahari}

Dibedakan menjadi tiga macam sumber pencahayaan alami dari matahari untuk bangunan (Szokolay et. al, 2001), yaitu:

1. Cahaya matahari langsung,

2. Cahaya difus dari terang langit,

3. Cahaya difus dari pantulan tanah atau bangunan lainnya.

Khusus wilayah yang memiliki iklim tropis, pencahayaan alami dari matahari langsung harus dihindari karena intensitas panasnya cukup tinggi selain mempengaruhi suhu ruangan yang menjadi kurang nyaman intensitas panasnya cahaya matahari langsung juga mampu menganggu kenyamanan thermal manusia pengguna bangunan. Dalam mengatasi cahaya matahari langsung dengan elemen sun shading atau penyaringpenyaring cahaya langsung seperti kisi-kisi dan sebagainya, dengan memanfaatkan bayangan dari sebuah fasad atau material sebagai sun shading tersebut. berlebih dapat dilakukan dengan mendesain bentuk bangunan yang disesesuaikan dengan kondisi iklim Terdapat dua cara pencahayaan yang bisa diterapkan yaitu cara 2 dan 3 . Perihal intensitas cahaya difus dari terang langit sangat bervariasi menyesuaikan keadaan kondisi terang langit saat cerah terang ataupun berawan. Tipe pencahayaan cahaya difus dari pantulan tanah atau bangunan lain dapat menimbulkan adanya sebuah cahaya berlebih (kesilauan) karena sudut datangnya cahaya yang juga rendah, tetapi itu juga merupakan solusi paling memungkinkan yang dapat digunakan dalam sebuah kawasan atau wilayah yang beriklim tropis dan sub-tropis.

Cahaya difus dari telang langit juga bisa di pantulkan dengan maksimal dengan elemen-elemen seperti cermin yang dapat memantulkan cahaya dari atas ke dalam sebuah ruangan dengan mudah. Selain itu pemilihan warna dinding, fasad, atau element lainnya juga harus dipilih dengan baik. Warna terang seperti putih memang dapat memantulkan cahaya yang baik ke dalam sisi interior ruangnya. Tapi semua intensitas cahaya atau lumens dalam sebuah ruangan berbeda-beda. Maka dari itu faktor masuknya cahaya yang masuk juga harus diatur dari matrial bahkan warna pada fasad yang terkana cahaya alami.

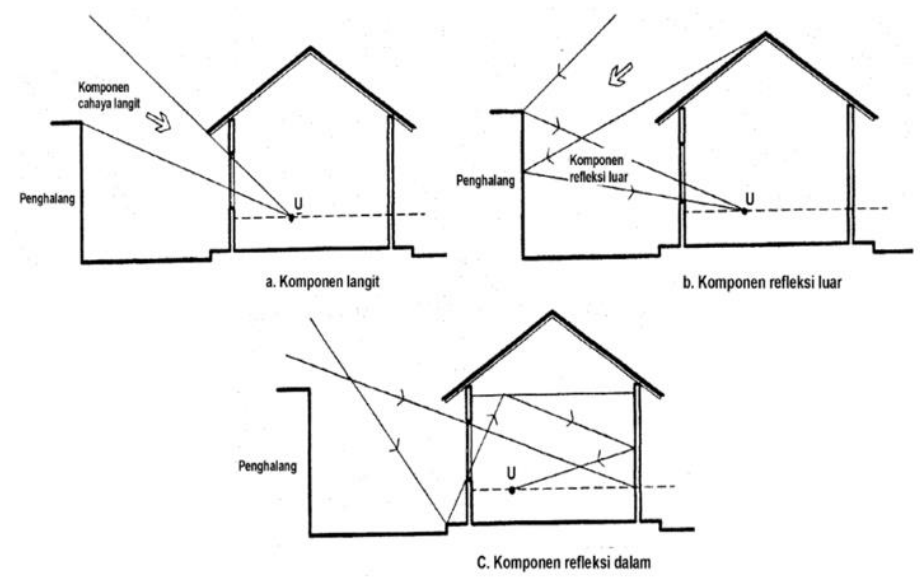

Gambar 1. Tata cara perancangan sistem pencahayaan alami pada bangunan gedung Sumber: SNI 03-2001 
Pantulan dan arah sinar matahari merupakan hal utama yang harus di perhatikan dalam pemanfaatan pencahayaan alami. Perlu di ketahui jumlah dan arah sinar matahari yang masuk ke dalam banguanan, sehingga pengaturan bukaan dan pemantulan cahaya matahari dapat menyaring jumlah sinar matahari yang masuk ke dalam bangunan. Dengan pengaturan dan perancangan yang sesuai akan mempengaruhi tingkat kenyamanan pada bangunan.

\section{Peletakan dan fungsi ruang}

Peletakan ruang sangat mempengaruhi pemanfaatan pencahayaan alami, di dasari dengan Analisa arah dan intensitas sinar matahari maka dapat menentukan peletakan dan fungsi ruang yang paling banyak terkena sinar matahari. Bangunan yang biasanya paling banyak interaksi dan aktifitas manusia lebih banyak memerlukan pencahayaan alami. Pada iklim tropis khusus nya di bali ruang - ruang yang biasanya menjadi zona public atau ruang yang mendukung fasilitas hotel biasanya di rancang dengan pencahayaan yang maksimal. Zona publik pada hotel yang paling umum dengan pencahayaan alami biasanya seperti lobby, restaurant, dan sport club. Selain zona public, pemanfaatan pencahayaan alami pada zona private seperti kamar hotel juga sering menjadi salah satu alternative dalam perancangan sebuah hotel resort samping menghemat energi pengunjung juga dapat merasakan suasana pada iklim tropis.

Terbukti cahaya alami sangat sekali mempengaruhi peletakan ruang. Biasanya mayoritas bangunan menghindari cahaya matahari barat atau matahari sore, dan sangat mengutamakan cahaya matahari pagi yang menyehatkan. Menariknya tapak resort adalah di pantai kuta, bali. Bukannya memblokade sebuah cahaya matahari sore justru malah menjadikannya sebuah keunggulan hotel resort pada wilayah ini. Karena mayoritas manusia suka menikmati matahari terbenam di pantai, atau bisa dibilang sunset adalah sebuah moment yang biasa bagi orang-orang menunggu dan menikmati tenggelamnya matahari dipantai. Maka dari itu pemanfaatan cahaya alam ini diharapkan dapat memanfaatkan potensi-potensi yang ada tanpa membuat hal-hal yang mengganggu kenyamanan thermal.

\section{Bentuk pada bukaan}

Bentuk bukaan pada bangunan mempengaruhi sinar matahari yang masuk dalam sebuah ruangan atau bangunan. Pemilihan bentuk rancangan pada bukaan atau jendela juga dapat di rancang dengan memperhatikan unsur ke indahan. Dengan bentuk bukaan yang di aplikasi kan dengan bentuk yang unik seperti ukiran akan menghasilkan pantulan atau cahaya sinar matahari yang masuk ke dalam ruangan memiliki pola atau unsur ke indahan. Salah satu rancangan yang di gunakan untuk pengolahan bentuk pencahayaan alami adalah second skin. Second skin merupakan lapisan pada luar dinding utama (façade) bangunan tetapi tidak menempel pada bagian tersebut. Lapisan ini dibuat oleh para arsitek untuk mengatasi panas sinar matahari yang masuk ke dalam bangunan.

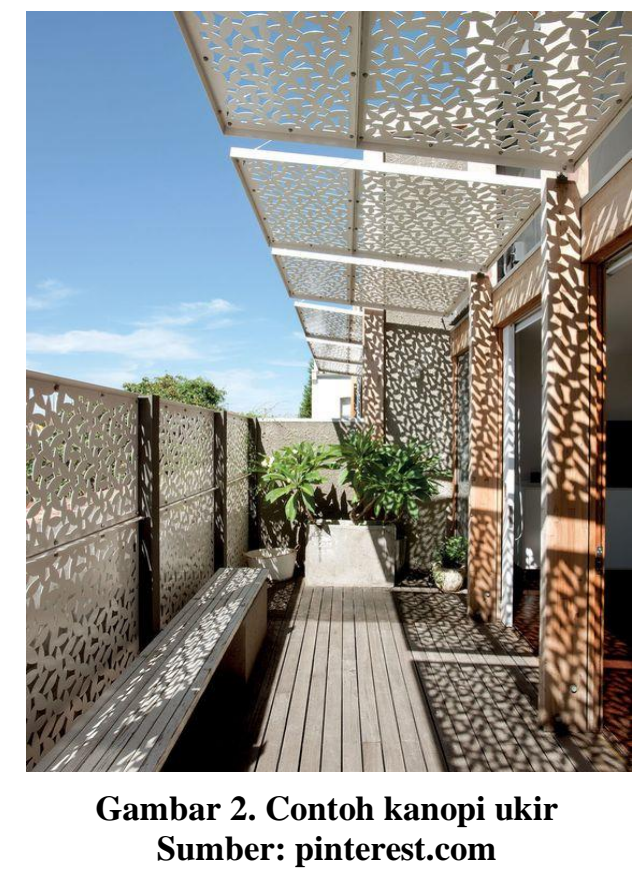


Dengan bentuk second skin atau design kanopi dan railing balok yang di buat dengan ukiran- ukiran maka terbentuk bayangan yang serupa pada pantulan cahaya sinar matahari yang masuk sehingga menambah unsur keindahan pada bangunan. Selain second skin juga ada rancangan bangunan yang di buat tanpa menggunakan dinding penutup yang biasa terdapat pada bagian lobby utama hotel.

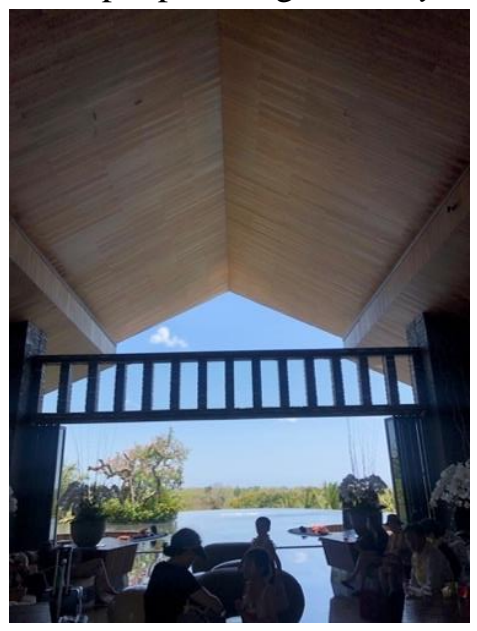

Gambar 3. Lobby hotel Ayana Bali Sumber: Data pribadi

Rancangan bangunan dengan floor to plafond yang tinggi dapat memaksimalkan jumlah cahaya yang masuk ke dalam ruangan, terlebih pada siang hari bangunan tidak memerlukan cahaya buatan seperti lampu dan bukaan pada bangunan juga meningkatkan kenyamanan untuk sirkulasi udara di dalam bangunan.

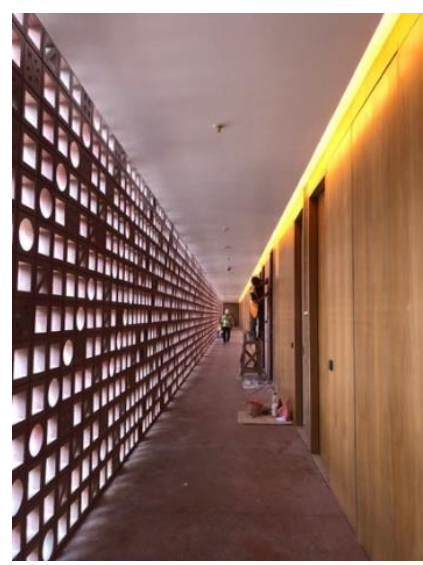

\section{Gambar 4. Rooster Koridor Hotel Potato Head} Sumber: Data Pribadi

Penempatan sebuah rooster pada koridor, yang menggantikan fungsi dinding atau kaca, ini bisa membuat difus cahaya yang sangat baik untuk sebuah koridor hotel, cahaya alami yang masuk akan tidak mengganggu kenyamanan thermal, dan pada iklim di bali ini selain cahaya yang dapat meminimalisir penggunaan listrik atau lampu sebagai cahaya buatan, rooster ini juga dpt mengalirkan udara dari luar ke dalam yang membuat keadaan thermal dalam ruangan lebih teratur dan mengurangi juga penggunaan ac dalam koridor.

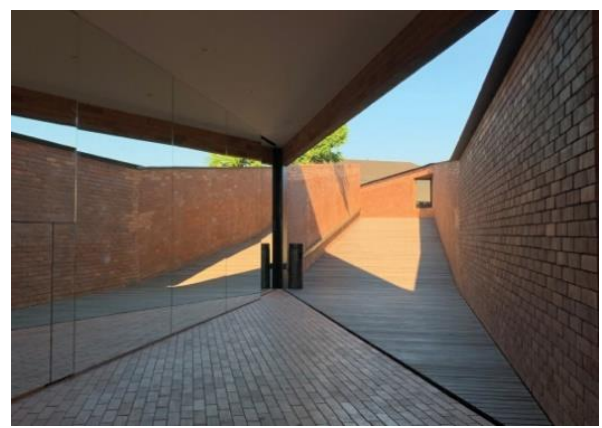

\section{Gambar 5. Entrance Titik Dua Bali Sumber: Google.com}


Contoh matahari difuse dengan kaca cermin seperti gambar ini, efek kaca cermin pada gambar selain bisa membuat efek ruangan menjadi lebih luas, cermin ini juga salah satu cara memaksimalkan pantulan cahaya langsung selain dengan warna fasad yang terang. Efek pada cermin pada bagian yang terlihat ke matahari seperti ini dapat dipakai pada iklim dibali, dengan memanfaatkan iklim dan cahaya matahari langsung difuse cahaya atau memantulkan seperti ini bisa sangat efektif pada ruang-ruang yang begitu dalam dan memerlukan cahaya alam, pantulan cahaya dari kaca cermin seperti ini akan lebih frontal memancarkan sebuah cahaya ke dalam ruang-ruang dalam.

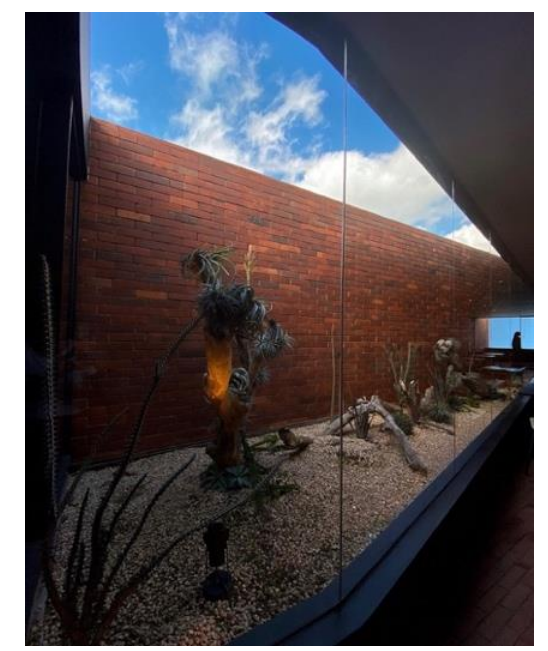

Gambar 6. Resepsionis Titik Dua Bali Sumber: Google.com

Penempatan cahaya matahari langsung, bisa Ditempatkan pada sebuah inner court, seperti pada gambar. Seperti yang dibutuhkan ruang-ruang publik pada hotel. Sebuah lobby atau ruang public lainnya membutuhkan intesitas cahaya yang besar. Pada gambar ini kita dapat melihat bagaimana cara matahari langsung masuk ke dalam lobby hotel. Dan dikarenakan matahari langsung maka cahaya yang masuk tidak berada dalam area yang bisa dilalui manusia karena akan mengganggu kenyamanan thermal, maka di area yang terjatuh cahaya langsung diberi border seperti inner court, kolam, dan sebagainya. Intesitas cahaya yang masuk sangat besar karena tidak ada difus pada bagian ini, menutup bagian view secara horizontal. Dengan dinding. Sehingga hanya cahaya langsung dari atas langit yang akan masuk. Cara ini juga bisa untuk menutupi view yang tidak diinginkan tapi satu sisi ingin mendapatkan cahaya alami.

\section{Kesimpulan}

Pencahayaan alami pada bangunan hotel resort di iklim tropis, memiliki banyak maanfaat seperti berkurangnya pemakaian lampu pada siang hari, adanya penghematan energi, meningkatkan kenyamanan pada sirkulasi udara serta mempengaruhi keharmonisan ruang dalam dan ruang luar.

Perancangan untuk pencahayaan alami juga harus memperhatikan arah dan pantulan cahaya sinar matahari, peletakan dan fungsi ruang, dan bentuk pada bukaan. Ketiga aspek tersebut sangat mempengaruhi kenyamanan dan kenyamanan thermal pada dalam bangunan, dan dengan memperhatikan aspek dapat di aplikasikan unsur keindahan pada bangunan.

Kesimpulannya pencahayaan alami dapat di manfaatkan melalui berbagai macam proses, misalnya dengan melakukan pemantulan cahaya melalui second skin pada fasad bangunan, Memaksimalkan ketinggian floor to plafond sehingga meningkatkan jumlah cahaya pada ruangan, melakukan difus cahaya dengan menggunakan berbagai material seperti penggunaan rooster pada dinding bangunan. Cahaya matahari langsung tanpa proses apapun juga dapat di manfaatkan pada hotel resort di iklim tropis. Hal tersebut biasanya di lakukan pada bagian ruangan yang tidak memiliki fungsi utama dan di lakukan hanya untuk meningkat unsur estetika pada bagian hotel resort. Pencahayaan alami yang di dapatkan melalui berbagai proses dapat menjadi potensi dan keunggulan pada desain hotel resort di daerah dengan iklim tropis khususnya di Pulau Bali.

\section{Referensi}

Adhitama, Satya \& Fathimah. (2016). Rekayasa Tata Cahaya Alami pada Ruang Laboratorium pada Program Studi Arsitektur Universitas Brawijaya.

Agus, Sulastiyono. (2011). Manajemen Penyelenggaraan Hotel: Manajemen. Hotel. Bandung: Alfabeta. 
Attahaillah. (2013). Simulasi Pencahayaan Alami pada Program Studi Arsitektur Universitas Malikussaleh.

Coltman, Michael M. (1989). "Resort Hotel Resort Is A Tourism Area in Which There Are Accommodation Facilities," Van Nostrand Reinhold, New York.

Dora P E \& Nilasari P F. (2011). Pemanfaatan Pencahayaan Alami pada Rumah Tinggal Tipe Townhouse di Surabaya. In: Seminar Nasional Living Green: Mensinergikan Kehidupan, Mewujudkan Keberlanjutan, Universitas Kristen Petra.

Karyono, Tri Harso, Prof, Ph. D. (2016). Arsitektur Tropis; Bentuk, Teknologi, Kenyamanan \& Penggunaan Energi. Erlangga, Jakarta.

Karyono, Tri Harso, Prof, Ph. D. (2016). Kota Tropis Dunia Ketiga: Suatu Bahasan tentang Indonesia, Grafindo, Jakarta.

Koenigsberger, Otto.H. (1975). Manual of Tropical Housing a Building Climatic Design.

Rahmania \& Sugini. (2013). Evaluasi Tingkat Kenyamanan Visual Yang Di Tinjau dari Aspek Pengoptimalisasian Pencahayaan Alami.

SNI 03-2396-2001 tentang Tata Cara Perancangan Sistem Pencahayaan Alami pada Bangunan Gedung. Badan Standardisasi Nasional.

SNI 03-6197-2000 tentang Konservasi Energi Sistem Pencahayaan pada Bangunan Gedung. Badan Standardisasi Nasional.

Talarosha, Basaria. (2004). Penerangan Alami Dan Bukaan Bangunan pada Program Studi Arsitektur Universitas Sumatera Utara.

Thojib, Jusuf. (1992). Kajian Rancangan Pencahayaan Alami dan Persepsi Pemakai pada Bangunan. 